\title{
TORSION OF THE APPENDIX
}

A. E. Carter, F.R.C.S.

St. Mary's Hospital, London, W.2

The dynamics of torsion, as occurring in abdominal viscera, are, commonly, poorly understood. What initiates the twist is a mystery, usually, though in some cases, for example the sigmoid colon, it may reasonably be accepted that an uneven weight distribution of the contents caused one part to fall over the other: perhaps peristaltic activity may set a torsion going in the small intestine, one loop slithering around another: perhaps, also, the pulsation of large arteries, so arranged as to run a spiral course, may by repeated pulses, set up such twisting forces that torsion occurs. Without doubt the structural situation, in which the involved structure is either fixed at either end and free elsewhere or is so narrowly based that its arrangement is like that of a fan, will predispose to torsion and in the large majority of cases this is the state of affairs found at the time of treatment.

As, once the torsion has started, venous obstruction and, later arterial occlusion combine to jeopardize the life of their supplied structure, the presence of bacterial life in a twisted viscus might be expected to be especially severe and productive of symptoms and signs, easily distinguished, and of rapidly increasing severity.

It is, perhaps, curious that, in an organ so commonly possessed of a narrowly based mesentery, torsion as a precedent to acute inflammation should not be seen more frequently. From time to time acute appendicitis associated with torsion of the appendix does occur and has been recorded in the British literature on four previous occasions (Payne, 1918; Bevers, I920; McFadden, I926; Flatley, 1936). Torsion occurs around the long axis of the appendix, producing strangulation and gangrene distal to the twist which may be through as many as $360^{\circ}$.

Eighteen continental and two American reports refer to the condition, though none earlier than that of Payne (1918) from Torquay.

Two cases are presented here, one in which the symptoms were of progressive acute appendicitis, the other with preceding 'appendicular colic' over the greater part of a day, culminating in progressive acute disease.

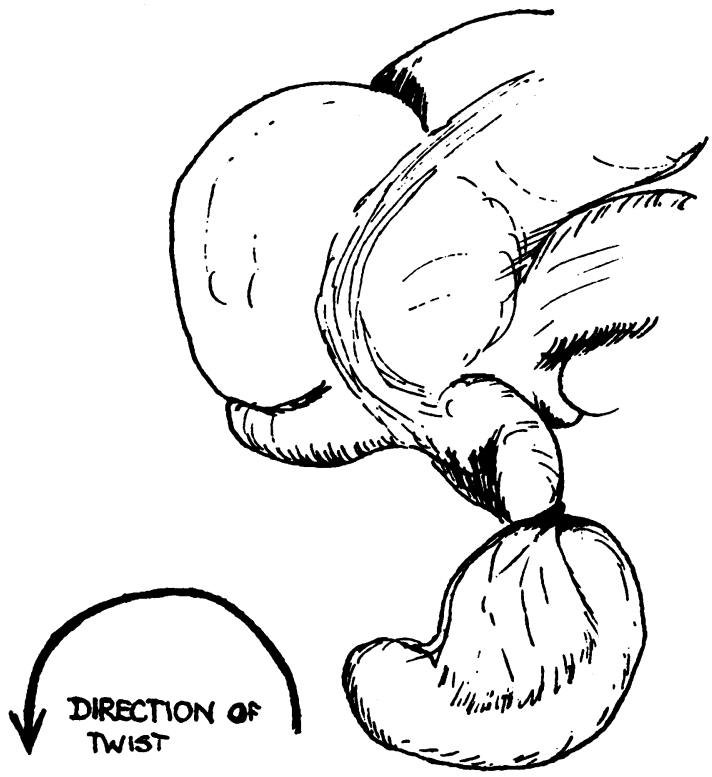

FIG. I

\section{Case I}

K.E., a little girl of eight years, came to hospital with only three hours' symptoms of severe, continuous generalized abdominal pain associated with vomiting of gastric contents on several occasions.

Examination showed a pyrexia of ror $^{\circ} \mathrm{F}$., tachycardia of 130 beats per minute and a generally tender abdomen with rigidity, extreme tenderness and rebound tenderness over the greater part of the right iliac fossa.

Appendicectomy was undertaken (A.E.C.) under general anaesthesia: the appendix was lying free and showed longitudinal torsion with early necrosis beyond the twist (Fig. I); there was moderate surrounding peritonitis.

After appendicectomy the child's recovery was uneventful.

\section{Case 2}

J.M., a strapping Irish lad of sixteen, had had 


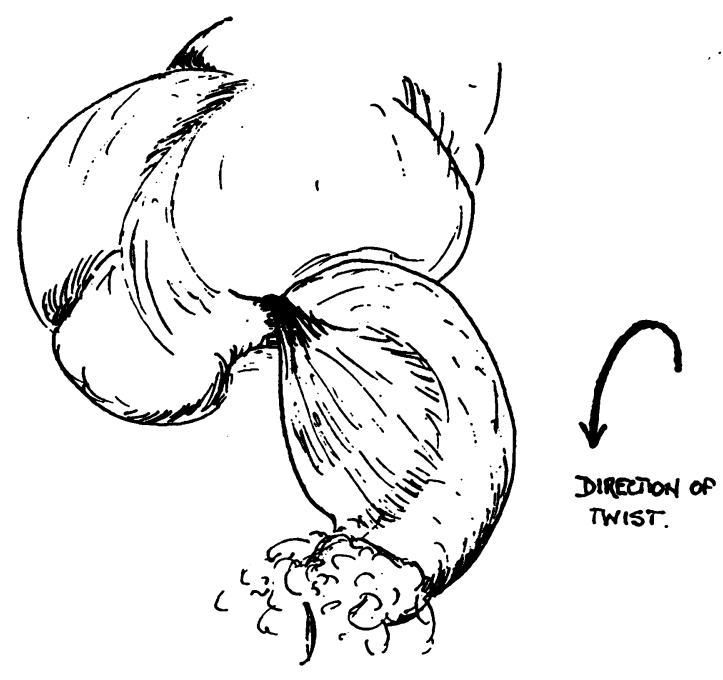

FIG. 2

central abdominal colic for most of the 24 hours before admission and had taken a 'dose of salts' only to make his symptoms worse. By the time he arrived at hospital his colic had been replaced by increasingly severe right iliac fossa pain with nausea but no vomiting.
His temperature was $99.4^{\circ} \mathrm{F}$., pulse 100 , and his tongue furred. The abdomen was rigid and tender in the right iliac fossa with marked rebound tenderness and a suggestion of a mass.

Appendicectomy was performed under general anaesthesia (A.E.C.), when, as in the first case, the appendix lay free, was twisted through more than $360^{\circ}$ and the distal part was gangrenous. The boy made an uneventful recovery.

\section{Comment}

These two cases are presented to illustrate the capacity of the appendix to undergo torsion with subsequent, but not necessarily immediate gangrene distally.

\section{Acknowledgments}

I wish to thank Mr. M. H. Harmer, of Paddington Green Children's Hospital, for permission to $\mathrm{w}$ treat Case $I$ and report the findings, and Mr. K. Owen, of St. Mary's Hospital, similarly for $\vec{O}$ Case 2.

\section{BIBLIOGRAPHY}

BEVERS, E. C. (1920), Lancet, i, 597.

FLATLEY, G. (1936), Ibid., i, 1357.

MCFADDEN, G. D. F. (1926), Brit. med. 7 ., ii, 1223.

PAYNE, J. E. (1918), Brit. F. Surg., 6, 327.

\section{DIETARY FAT, CHOLESTEROL METABOLISM \& CORONARY DISEASE}

(Postgraduate Medical fournal, April r 959)

Price 6s. 6d. post free

\section{THE EPIDEMIOLOGY OF ISCHAEMIC HEART DISEASE \\ B. Bronte-Stewart, M.D., M.R.C.P. \\ THE REgULATION OF THE HUMAN SERUM-CHOLESTEROL LEVEL \\ H. Gordon, M.D. (Cape Town)}

THE RELATIONSHIP BETWEEN THE SERUM LIPIDS AND THE DEVELOPMENT OF ISCHAEMIC HEART DISEASE B. Bronte-Stewart, M.D., M.R.C.P.

THE COAGULABILITY OF BLOOD IN RELATION TO CORONARY HEART DISEASE

C. Merskey, M.D. (Cape), M.R.C.P. (London), and H. Lackner, M.D. (Leeds), M.R.C.P. (London)
THE METABOLISM OF CHOLESTEROL

B. Lewis, Ph.D., M.D. (Cape Town)

PRESENT CLINICAL APPLICATIONS OF DIET TO THE PREVENTION OF ISCHAEMIC HEART DISEASE

J. F. Brock, D.M., F.R.C.P.

MYOCARDIAL INFARCTION-THE COMPARATIVE RACIAL PREVALENCE IN CAPE TOWN, 1957-AN ELECTROCARDIOGRAPHIC STUDY

V. Schrire, M.Sc., Ph.D., M.B., Ch.B. (Cape Town), M.R.C.P. (London and Edinburgh)

ISCHAEMIC HEART DISEASE IN AFRICAN POPULATIONS

J. F. Brock, D.M., F.R.C.P., and H. Gordon, M.D. (Cape Town)

Published by

THE FELLOWSHIP OF POSTGRADUATE MEDICINE

60, Portland Place, London, W.1 